\title{
Francis P. Conant: A Tribute to a Friend of Human Ecology
}

\author{
Daniel G. Bates
}

Published online: 31 March 2011

(C) Springer Science+Business Media, LLC 2011

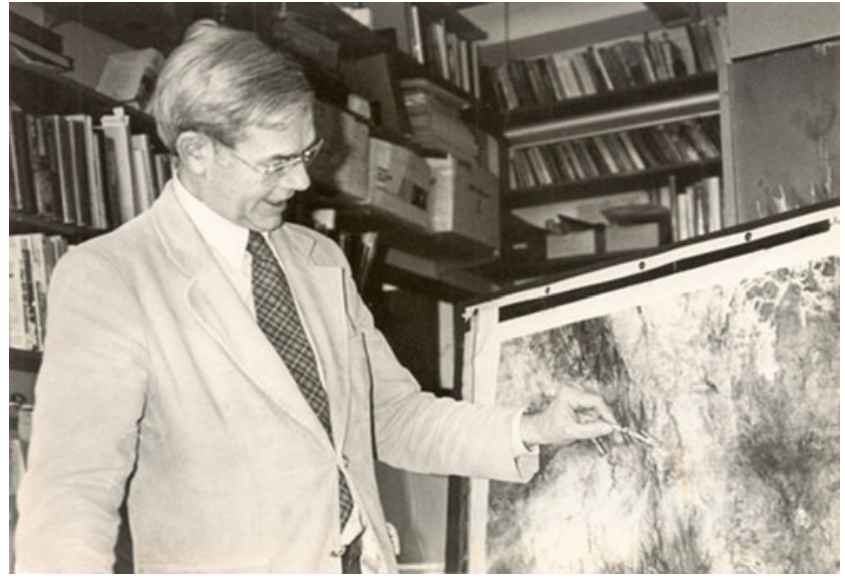

Francis Paine Conant, Emeritus Professor of Anthropology at Hunter College, City University of New York, where he taught for over three decades, died early Saturday morning January 29, 2011.

Frank Conant was actively involved with Human Ecology: An Interdisciplnary Journal almost from its inception in 1973. For over 30 years he actively reviewed manuscripts, books, and occasionally submitted articles. His reviewing was particularly important to the journal in establishing it as a venue for the developing interest in satellite data and GIS applications in ecological research.

D. G. Bates $(\square)$

Department of Anthropology, Hunter College,

C.U.N.Y., 695 Park Avenue,

New York, NY 10065, USA

e-mail: humaneco@hunter.cuny.edu
This is a field in which Frank was definitely an "early adopter" in the social sciences, beginning long before the convenience of desktop computing and the Internet. Conant's pioneering work with the application of remote sensing data from Landsat satellites began in 1974 when the late Priscilla Reining of the AAAS showed him Landsat imagery for the area of his fieldwork in Nigeria. In 1977 he set up a NSF sponsored remote sensing monitoring area in West Pokot district in Kenya. There he conducted trial uses of Landsat data relating to shifting cultivation patterns and livestock management. He also used this tool to investigate the impact of widespread banditry on the Ugandan border. In further research he emphasized the role of cultural values in the interpretation of satellite data.

Another area in which his insightful reviewing played an important role in the growth of the journal was in vetting work on arid zone pastoralism. Today Human Ecology has published more articles on what might be termed "traditional" animal husbandry than any other journal in the environmental sciences.

As a scholar, he has a prominent place among a very distinguished group of early post World War II American scholars who shaped contemporary ethnology by building on earlier, mostly British, traditions of developing theory based on ethnographic research in Africa. He was a fellow of the American Anthropological Association, the American Association for the Advancement of Science (AAAS), the International African Institute, the New York Academy of Sciences, the Royal Anthropological Institute, and member of the Society for Applied Anthropology. His lifelong interest in technology led to awards for making ethnographic collections for the American Museum of Natural History in New York, where a diorama he created is on permanent display.

He will be keenly missed. 